\title{
Study on the Uncoupling Characteristics of PEM Fuel Cell by Segmented Cell Technology
}

\author{
Bowen Feng, Rui Lin", Dengcheng Liu, Di Zhong \\ School of Automotive Studies, Tongji University, Shanghai 201804, Shanghai, China \\ *E-mail: ruilin@tongji.edu.cn (Rui Lin).
}

doi: $10.20964 / 2019.03 .12$

Received: 3 November 2018 / Accepted: 1 January 2019 / Published: 7 February 2019

The segmented cell technology can provide real-time spatial current density distribution of PEM fuel cell. This technology was originally applied only to the anode of the cell. Normally, the anode and cathode reactions of the cell were coupled and the overall performance was the same. However, for PEM fuel cell, the local performance of cathode and anode would be uncoupled due to the influence of reaction gas distribution and water distribution. In this paper, for the first time, the technology was used on anode and cathode simultaneously. It used multi-layered printed circuit board(PCB) flow field plates to substitute both anode plate and cathode plate. The mapping of current density distribution of the anode and the cathode could be tested at the same time. The local difference of cathode and anode performance was investigated at different relative humidity. It showed that anode had better performance at hydrogen inlet while cathode had better performance at the inlet part of air. The cell was operated at 5A, 25A and $45 \mathrm{~A}$ constant current conditions(respectively represented low, medium and high load states). With the increase of operating current density, the percentage difference was also increased.

Keywords: PEM fuel cell; uncoupling characteristics; relative humidity

\section{$\underline{\text { FULL TEXT }}$}

(C) 2019 The Authors. Published by ESG (www.electrochemsci.org). This article is an open access article distributed under the terms and conditions of the Creative Commons Attribution license (http://creativecommons.org/licenses/by/4.0/). 